\title{
$T$ cell- but not tumor cell-produced TGF- $\beta 1$ promotes the development of spontaneous mammary cancer
}

\author{
Abira Sarkar ${ }^{1}$, Moses K. Donkor ${ }^{1}$, and Ming O. Li ${ }^{1}$ \\ ${ }^{1}$ Immunology Program, Memorial Sloan-Kettering Cancer Center, New York, NY 10065 \\ Correspondence to: Dr. Ming O. Li, email: lim@mskcc.org \\ Keywords: TGF- $\beta$, T cell tolerance, immunosurveillance, tumor immunity, metastasis, immunotherapy \\ Received: December 22, 2011, Accepted: December 23, 2011, Published: December 31, 2011
}

Copyright: ( Sarkar et al. This is an open-access article distributed under the terms of the Creative Commons Attribution License, which permits unrestricted use, distribution, and reproduction in any medium, provided the original author and source are credited.

ABSTRACT:

\begin{abstract}
During their development, tumors acquire multiple capabilities that enable them to proliferate, disseminate and evade immunosurveillance. A putative mechanism is through the production of the cytokine TGF- $\beta 1$. We showed in our recent studies that $T$ cell-produced TGF- $\beta 1$ inhibits antitumor $T$ cell responses to foster tumor growth raising the question of the precise function of TGF- $\beta 1$ produced by tumor cells in tumor development. Here, using a transgenic model of mammary cancer, we report that deletion of TGF- $\beta 1$ from tumor cells did not protect mice from tumor development. However, ablation of TGF- $\beta 1$ from $T$ cells significantly inhibited mammary tumor growth. Additionally, absence of TGF- $\beta 1$ in T cells prevented tumors from advancing to higher pathological grades and further suppressed secondary tumor development in the lungs. These findings reveal $\mathrm{T}$ cells but not tumor cells as a critical source of TGF- $\beta 1$ that promotes tumor development.
\end{abstract}

\section{INTRODUCTION}

The biology that underlies tumor development is complex. Starting from tumor initiation, subsequent to cellular transformation, tumors undergo dramatic evolution[1]. During this multistep process, studies have demonstrated that tumors abandon most of the key features associated with normal cells and acquire capabilities that serve the ultimate goal of sustaining tumor cell survival and proliferation[1]. Indeed, the functional role of each of the hallmarks of cancer including proliferative signaling, evading growth suppressors, resisting death, enabling replicative immortality, inducing angiogenesis, and activating invasion and metastasis either directly or indirectly promotes tumor cell survival and/or proliferation[1]. While these hallmarks are intrinsic to tumor cells, growing evidence suggests that it is the totality of the tumor microenvironment that determines the outcome of carcinogenesis[1-3].

The immune system is postulated to recognize tumors and to protect the host from tumor development in a framework described as cancer immunosurveillance[4-6]. The immunosurveillance hypothesis envisaged that this function of effector leukocytes in defense against cancer would be necessary to maintain tissue homeostasis similar to its protective role against pathogenic microbes. Studies in mice have demonstrated that deficiency in recombination-activating gene (Rag)- 1 or -2 required for the development of adaptive immunity results in increased frequency, shortened tumor latency, faster tumor growth kinetics of chemical-induced sarcomas and increased development of a broader spectrum of spontaneous tumors compared to age-matched wild type littermates[6-8]. Tumors that develop under immunodeficient Rag-2 knockout conditions are rejected when transplanted into wild type recipients but develop in hosts depleted of $\mathrm{CD}^{+}{ }^{+}$or $\mathrm{CD} 8^{+} \mathrm{T}$ cells $[7,9]$. Moreover, tumors derived from wild type mice are not rejected when transferred into either wild type mice or Rag-2-deficient hosts[7, 9]. These findings support the immunosurveillance hypothesis and further demonstrate that $\mathrm{T}$ cells not only mediate tumor elimination but can also shape the immunogenicity of tumors.

Recently, some effector mechanisms that mediate lymphocyte-dependent tumor rejection have been defined. Modification of tumor cells to secrete interferon (IFN)- $\gamma$ resulted in the induction of persistent specific $\mathrm{T}$ cell immunity and a $\mathrm{CD} 8^{+} \mathrm{T}$ cell-dependent tumor rejection whereas treatment of wild type mice with antibodies to neutralize endogenous IFN- $\gamma$ led to failed rejection of carcinogen-induced tumors[10-12]. In addition to 
IFN- $\gamma$, the cytotoxic granule pathway has been shown to be essential for immunosurveillance. Deficiency in perforin, a crucial pore-forming protein required for the killer function of CTLs and natural killer cells results in development of fibrosarcomas with reduced latency and greater incidence and the mice further show greater susceptibility to the development of B cell lymphomas in comparison to control wild type mice[13-16]. These findings collectively underscore type 1-lymphocyte responses in the immunosurveillance of spontaneous and MCA-induced tumors.

However, for the vast majority of tumor types, immune-mediated tumor rejection is not observed. In a transgenic model of sporadic cancer, the wellcharacterized SV40 Tag oncogene is stochastically activated leading to tumor development in diverse unpredictable tissues[17]. In this model, $\mathrm{CD}^{+} \mathrm{T}$ cells recognize the Tag tumor-associated antigen but fail to kill target cells when tested in vivo[17]. In the TRAMP (transgenic adenocarcinoma of mouse prostate) model of prostate cancer, our recent findings, together with previous observations, demonstrated that $\mathrm{HRC} \mathrm{CD}^{+}$ $\mathrm{T}$ cells specific for the TRAMP self-antigen histone $\mathrm{H} 4$ show functional defects $[18,19]$. $\mathrm{CD}^{+} \mathrm{T}$ cells specific to tumor antigens have also been described in a subset of cancer patients but similar to the animal models, these $\mathrm{T}$ cells show limited effector activity[20,21]. These findings collectively suggest that $\mathrm{T}$ cells are able to recognize their cognate tumor antigens but the tumors avoid destruction by inducing $\mathrm{T}$ cell tolerance.

How tumors initially prime $\mathrm{T}$ cell recognition and subsequently escape $\mathrm{T}$ cell-mediated eradication remains poorly understood. Understanding the mechanistic underpinnings of $\mathrm{T}$ cell tolerance in tumors is fundamental to the development of more effective anticancer therapies. It is conceivable that the six hallmarks of cancer that functionally converge on tumor cell survival and chronic proliferation can each influence antitumor immune response. Indeed, the acquisition of each succeeding hallmark capability likely represents an evolutionary step whose success would require some escape from immune barrier to tumor progression. In addition, studies have shown that other cell-biologic behaviors of tumors do not favor the generation or function of effector $\mathrm{T}$ cells. For example, tumors are frequently associated with downregulation of MHC class I, impaired antigen presentation, lack of costimulation, exapansion and activation of suppressor cells which results in defective T cell responses to tumors [2, 22, 23].

The tumor microenvironment is a dynamic complex milieu consisting of the tumor, stromal cells such as fibroblasts and immune cells, vascular and lymphatic networks and the extracellular matrix. Beside providing a supportive stroma, studies have revealed that host cells can also influence tumor phenotype by supplying a variety of bioactive agents such as growth factors, cytokines and chemokines that can modulate tumor growth[1-3, 24]. It is possible that tumor progression requires these secreted factors although given the growth autonomy that malignancies acquire during their evolution it remains unclear as to what extent tumors depend on these factors for their growth. Recent studies have shown that the function of these secreted factors in tumors is in large part the inhibition of antitumor immune responses [1-3, 24].

The identity, sources and mechanisms of how some of these secreted factors regulate $\mathrm{T}$ cell responses to tumors have begun to be understood. In the stochastic model of cancer, Willimsky and Blankenstein showed that the development of defective tumor-specific $\mathrm{T}$ cell responses is coincident with loss of IFN- $\gamma$ response and the acquisition of elevated levels of the cytokine transforming growth factor (TGF)- $\beta 1$ in the circulation[25]. Systemic levels of TGF- $\beta 1$ are also associated with $\mathrm{T}$ cell dysfunction in cancer patients where it is a negative prognostic indicator[26]. TGF- $\beta$ is a family of three isoforms comprising TGF- $\beta 1,2$ and 3 . It is secreted as an inactive latent ligand that requires activation catalyzed by a variety of factors including proteases and integrins [27-31]. Once the active ligand is liberated, it binds the serine or threonine kinases TGF- $\beta$ type I (TGF$\beta R I)$ and type II (TGF- $\beta$ RII) receptors, which recruit and phosphorylate Smad2 and Smad3 transcription factors[28, 29, 32]. Activated Smad2 and Smad3 proteins dimerize and complex with Smad4 and translocate to the nucleus to regulate Smad-dependent genes[28, 29, 32]. Studies have shown that TGF- $\beta$ exerts antiproliferative effects on epithelial cells by transcriptional repression of c-Myc and induction of inhibitors of cyclin-dependent kinases, which are important for cell cycle entry and progression[29]. In addition, TGF- $\beta$ profoundly represses lymphocyte proliferation and differentiation and autoreactive function[28, 32-37].

In a variety of tumor types, TGF- $\beta$ has been suggested to play an important role in tumor progression[38]. At the early stage of tumor development, TGF- $\beta$ is thought to regulate cellular homeostasis by enforcing cytostasis, differentiation and apoptosis of tumor cells[39, 40]. Indeed, transgenic expression of a dominant negative mutant of TGF- $\beta$ RII (DNR) in prostate epithelium accelerates tumor development and reduces tumor latency in TRAMP mice, underscoring a suppressive function of TGF- $\beta$ in tumorigenesis[41]. However, studies show that some tumors can circumvent the suppressive effects of TGF- $\beta$ via mutations in TGF- $\beta$ receptors or downstream alterations that disable the tumor suppressor arm of the TGF- $\beta$ pathway $[42,43]$. Autocrine TGF- $\beta$ signaling is then thought to promote tumor progression via regulation of the invasion-metastasis cascade involving epithelialto-mesenchymal transition, invasion of regional tissue, dissemination and metastatic colonization [29].

In contrast to this prevailing model that emphasizes the effect of TGF- $\beta$ signaling on tumors, recent studies 
suggest that TGF- $\beta$ regulation of $\mathrm{T}$ cell responses to tumors is an integral part of tumor development[18, 44-47]. Consistent with these observations, we recently demonstrated that failure to control TRAMP tumor growth by adaptive immunity arises from $T$ cell-intrinsic TGF- $\beta$ signaling that initiates at the tumor-draining lymph nodes[18]. TRAMP tumors, like most tumors, are sensitive to TGF- $\beta$ ligands but the requirement of TGF- $\beta$ signaling for the development of these tumors remains to be determined. Nonetheless, these observations suggest that $\mathrm{T}$ cell-intrinsic TGF- $\beta$ signaling probably exercises greater control on tumor development in comparison to tumor responsiveness to TGF- $\beta$. Importantly, it can be inferred from these findings that the varied tumor immunoevasion strategies and the cell-intrinsic hallmarks of cancer can be overruled by blocking TGF- $\beta$ signaling in T cells.

Diverse cell types in normal tissues produce TGF- $\beta 1$ and its production may further be upregulated in response to tumor development $[34,48-50]$. There is, however, a strong sense that tumor secretion of TGF- $\beta 1$ is a major mechanism of $\mathrm{T}$ cell tolerance $[44,51-53]$. It has been shown that overexpression of an active form TGF- $\beta 1$ in an immunogenic tumor cell results in inhibition of CTLmediated tumor rejection when inoculated into mice[53]. On the basis of this overexpression study and other succeeding studies, it was concluded that tumors produce TGF- $\beta 1$ to evade immune control[44, 51, 52]. Tumor secretion of TGF- $\beta 1$ is therefore conceptualized to dampen $\mathrm{T}$ cell reactivity at the tumor microenvironment where $\mathrm{T}$ cells are exposed to large quantities of TGF- $\beta 1$ produced by tumor cells. Contrary to this view, we demonstrated in our recent studies that $\mathrm{T}$ cell-specific deletion of TGF- $\beta 1$ protected mice against tumor growth and metastasis independent of TGF- $\beta 1$ produced by tumor cells[18]. In $T g f b 1^{\mathrm{ffh}} \mathrm{Cd} 4$ cre-TRAMP mice, we found that protective tumor immunity was associated with $\mathrm{T}$ cell differentiation into IFN- $\gamma$ - and granzyme (Gzm)B-producing effectors in the tumor draining lymph nodes and prostate[18] in line with reports showing that TGF- $\beta 1$ suppressess antitumor immunity by transcriptional repression of the CTL program including the expression of IFN- $\gamma$ and GzmB[54]. These studies provide compelling evidence that $\mathrm{T}$ cell TGF- $\beta 1$ fosters $T$ cell tolerance in tumors and is essential for tumor growth. Importantly, these observations do not support an essential role for TGF- $\beta 1$ produced by tumor cells in the development of these tumors. Nevertheless, in the absence of experimental approaches that assess the definitive function of tumor-produced TGF- $\beta 1$, evidence against tumors as the critical source of TGF- $\beta 1$ that inhibits immunosurveillance would be incomplete.

In this study, we addressed the specific function of tumor-produced TGF- $\beta 1$ in tumor development by crossing mice carrying floxed/null alleles of $T g f b 1$ to the Mmtvcre deleter mouse strain in which cre recombinase directs deletion of the $T g f b 1$ allele from mammary epithelium[55]. The $T g f b 1^{\mathrm{f} / \mathrm{n}}$ Mmtvcre line and the $T g f b \mathrm{f}^{\mathrm{ftn}}$
Cd4cre line used in our previous studies[18] were further crossed to the polioma middle $\mathrm{T}$ antigen (PyMT) mice in which the transgenic mice develop highly aggressive mammary adenocarcinoma that metastasizes to the lungs[56]. We found that tumor growth and pulmonary metastasis were comparable between $T g f b 1^{\mathrm{ffn}}$ MmtvcrePyMT and control $T g f b 1^{\mathrm{f} / \mathrm{n}}$-PyMT littermates. However, deletion of TGF- $\beta 1$ from $\mathrm{T}$ cells inhibited tumor development and protected PyMT mice from pulmonary metastasis. These findings establish that TGF- $\beta 1$ produced by $\mathrm{T}$ cells, but not tumor cells, is required for tumor growth and metastasis in PyMT mice. These observations further extend the generality of the requirement of TGF- $\beta 1$ produced by $\mathrm{T}$ cells in the development of spontaneous tumors. ResultsDeletion of tumor-produced TGF- $\beta 1$ does not affect tumor growth and metastasis in PyMT mice

In addition to the cell intrinsic hallmarks of cancer, tumors require other enabling mechanisms to achieve their survival and chronic replication program[1]. Studies show that the ability to evade immune eradication via TGF- $\beta$-mediated tolerance induction is a crucial survival mechanism for tumors[1, 2, 39, 48, 57, 58]. Recently, we demonstrated a non-redundant function of TGF- $\beta 1$ produced by $\mathrm{T}$ cells in tumor development [18], which leaves open the exact function of TGF- $\beta 1$ produced by tumors in tumor development. To rigorously test the requirement of tumor TGF- $\beta 1$ for the development of spontaneous tumors, we employed genetic approach targeting TGF- $\beta 1$ produced by tumor cells. To this end, we bred mice carrying floxed/null alleles of $T g f b 1$ $\left(T g f b 1^{f / n}\right)$ mice to the Mmtvcre deleter strain in which the cre recombinase instructs allelic recombination in mouse mammary epithelium[55]. Tgfbl $1^{\mathrm{f} / \mathrm{n}}$ Mmtvcre mice were further crossed to PyMT mice to obtain $T g f b 1^{\mathrm{f} / \mathrm{n}}$ Mmtvcre-PyMT mice. By RT-PCR analysis, we verified that TGF- $\beta 1$ is specifically deleted in tumor cells but not lymph node cells of tumor-bearing $T g f b 1^{\mathrm{fth}}$ Mmtvcre-PyMT mice (Figure 1A). To assess the effect of TGF- $\beta 1$ deficiency in tumor cells on the development of autochthonous mammary tumors, we monitored the mice for tumor growth. We found no differences between $T g f b 1^{\mathrm{f} / \mathrm{n}}$ Mmtvcre-PyMT and their littermates $T g f b 1^{\mathrm{f} / \mathrm{n}}$ PyMT when evaluated for tumor latency, tumor burden at the age of 20 weeks or the age at which the tumors reach the predetermined size of $2500 \mathrm{~mm}^{3}$ (Figure 1B and 1C).

Tumor pathogenesis has remarkable complexity that can manifest itself at more than one stage in the evolution of tumors. Thus, primary tumor size per se may not capture the full functional spectrum of a given signaling pathway on carcinogenesis. Metastatic dissemination is the primary cause of tumor-associated death in a very high proportion of cancer patients[59]. Tumor progression in the PyMT model recapitulates key features of human breast cancer including high incidence of secondary tumor development in the lung[56]. When $T g f b 1^{f / n}$ Mmtvcre-PyMT mice and the $T g f b 1^{\mathrm{f} / \mathrm{n}}$-PyMT cohorts with comparable tumor burden 
were evaluated for pulmonary metastasis, we found comparable tumor burden in the lungs (Figure 1D). These observations collectively suggest that tumor growth and metastasis in PyMT mice do not require TGF- $\beta 1$ produced by tumor cells.Inactivation of $\mathrm{T}$ cell TGF- $\beta 1$ inhibits tumor development in PyMT mice

By virtue of the widely reported role of TGF- $\beta 1$ produced by tumor cells in tumor development[44, 51-53], it was quite unexpected to find that deletion of TGF- $\beta 1$ from tumor cells neither affected primary tumor growth nor tumor metastasis compared to control littermates (Figure 1B, 1C and 1D). Next, we turned out attention to the role of TGF- $\beta 1$ produced by T cells in the development of PyMT tumors. In our earlier studies, we demonstrated that $\mathrm{T}$ cells provide the critical source of TGF- $\beta 1$ that promotes immunotolerance and tumor development in the TRAMP model of prostate cancer[18]. Specifically, we demonstrated that the inhibitory effect of TGF- $\beta 1$ resides in TGF- $\beta 1$ produced by $\mathrm{Ox} 40^{+}$subpopulation of $\mathrm{T}$ cells that consists predominantly of activated $\mathrm{CD}^{+} \mathrm{T}$ cells and $\mathrm{CD}^{+} \mathrm{Foxp}^{+} \mathrm{T}$ cells (Tregs)[60]. Thus, we became interested in the broader applicability of $\mathrm{T}$ cell produced TGF- $\beta 1$ in tumor development. To investigate the function of T cell-derived TGF- $\beta 1$ in mammary carcinogenesis, we

Table 1: Pathologic scoring for stages of tumor development in the mammary glands of littermates of $\mathrm{Tg}_{\mathrm{fb}}{ }^{\mathrm{f} / \mathrm{n}} \mathrm{Cd} \mathrm{Cre}$ PYMT and $\boldsymbol{T g} \boldsymbol{f} \boldsymbol{b} \mathbf{1}^{\mathbf{f} / \mathbf{n}}$ PYMT mice at $\mathbf{2 0}$ weeks of age. The values are average percentages of the stages of 4 pairs of littermates reviewed by identifying tumor stages by area and expressing each stage as a $\% \pm$ SEM The normal $\%$ represents the percentage area within the mammary gland with no visible tumor.

\begin{tabular}{|l|l|l|l|l|l|}
\hline Stage & Normal (\%) & I (\%) & II (\%) & III (\%) & IV (\%) \\
\hline Tgfb1 1/n_PyMT & $16.5 \pm 6.8$ & $11.6 \pm 3.7$ & $9.3 \pm 5.8$ & $6.9 \pm 3.9$ & $55.6 \pm 12.3$ \\
\hline Tgfb1 1/n Cd4cre-PyMT & $39.7 \pm 26.0$ & $20.7 \pm 9.1$ & $22.0 \pm 8.6$ & $9.2 \pm 4.2$ & $8.4 \pm 16.8$ \\
\hline
\end{tabular}

A

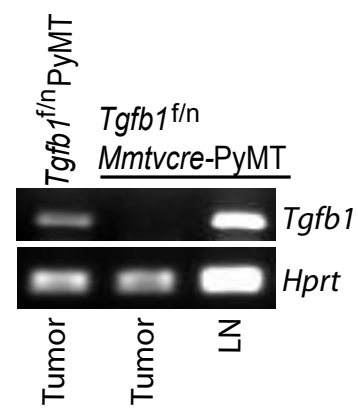

C

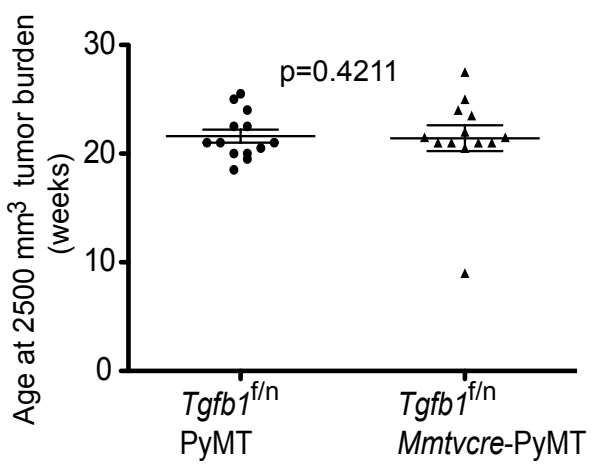

B

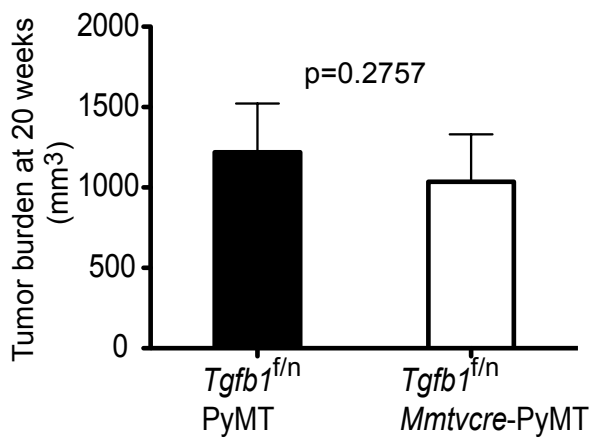

D

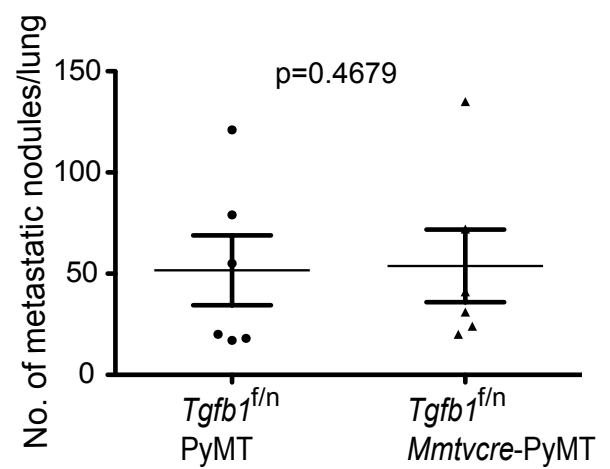

Figure 1: Absence of TGF- $\beta 1$ produced by mammary tumor cells does not affect tumor growth. (A) RT-PCR analysis of Tgf $\beta 1$ and Hprt expression from FACS-sorted tumor cells of control $T g f b 1^{\mathrm{f} / \mathrm{n}}$ PYMT mice, and from tumor cells and lymph node cells of $T g f b 1^{\mathrm{f} / \mathrm{n}}$ Mmtvcre-PYMT mice. LN; lymph node (B) Total tumor burden in all mammary glands of $T g f b 1^{\mathrm{f} / \mathrm{n}} M m t v c r e-\mathrm{PYMT}$ (n=9) and control Tgfb $1^{\mathrm{f} / \mathrm{n}}$ PYMT $(\mathrm{n}=9)$ mice at 20 weeks of age. Tumor volume was calculated using the formula $\mathrm{L} \mathrm{x} \mathrm{W}^{2} \mathrm{x} 0.52$ (where $\mathrm{L}$ is the longest diameter and $\mathrm{W}$ is the smallest diameter.) (C) The age at which $T g f b 1^{\mathrm{f} / \mathrm{n}}$ Mmtvcre-PYMT (n=9) and littermate control $T g f b 1^{\mathrm{f} / \mathrm{n}} \mathrm{PYMT}$ mice $(\mathrm{n}=9)$ achieved the predetermined tumor burden of $2500 \mathrm{~mm}^{3}$. (D) Total pulmonary metastatic nodules in $T g f b I^{\mathrm{f} / \mathrm{n}}$ Mmtvcre-PYMT (n=5) and control $T g f b 1^{\mathrm{f} / \mathrm{n}}$ PYMT (n=6) mice were assessed at a tumor burden of $2500 \mathrm{~mm}^{3}$. The $\mathrm{p}$ values between the two groups of tumor burden (B) age (C) and number of metastatic nodules (D) are shown (Students t-test). 
crossed the $T g f b 1^{\mathrm{f} / \mathrm{n}} C d 4 c r e$ line to PyMT mice to generate $T g f b 1^{\mathrm{f} / \mathrm{n}}$ Cd4cre-PyMT mice. When evaluated for tumor growth, we found that tumor burden at 20 weeks of age was significantly lower in $T g f b 1^{\mathrm{f} / \mathrm{n}}$ Cd4cre-PyMT mice compared to control $T g f b 1^{\mathrm{f} / \mathrm{n}}$-PyMT mice (Figure 2A). In cancer patients, higher pathological grade correlates with poorer survival outcome[62]. By histopathological analysis, we found that, on average, $40 \%$ of the mammary glands in $T g f b 1^{\mathrm{f} / \mathrm{n}} \mathrm{Cd} 4 \mathrm{cre}$-PyMT mice were normal whereas over $60 \%$ of the mammary glands analyzed in $T g f b 1^{\mathrm{f} / \mathrm{n}}$-PyMT mice had histological grade III or higher (Table 1). Thus a considerable proportion of the mammary glands in $T g f b 1^{\mathrm{f} / \mathrm{n}} \mathrm{Cd} 4 \mathrm{cre}$-PyMT mice were prevented from advancing to higher histological grades. In contrast In addition, the tumors in $T g f b 1^{\mathrm{f} / \mathrm{n}} C d 4 c r e$-PyMT mice grew at a slower rate reaching a volume of $2500 \mathrm{~mm}^{3}$ in approximately 25 weeks of age whereas it took $T g f b 1^{\mathrm{f} / \mathrm{n}}$ PyMT mice only 20 weeks to reach the same tumor burden (Figure 2B). Thus, tumor latency is increased and tumor growth kinetics reduced in $T g f b 1^{\mathrm{f} / \mathrm{n}} \mathrm{Cd} 4 \mathrm{cre}$-PyMT mice compared to littermate $T g f b 1^{\mathrm{f} / \mathrm{n}}$-PyMT mice.

The requirement for mammary tumor growth on TGF- $\beta 1$ produced by $\mathrm{T}$ cells is consistent with our previous reports[18]. However, in the TRAMP model, it was not possible to select mice with comparable tumor burden, a parameter that has been shown to be coupled to metastatic risk[61]. We circumvented this limitation by employing B16-OVA and EL-4 metastasis assay where we found that, similar to primary tumor growth, T cellproduced TGF- $\beta 1$ was required for the metastasis of these tumors[18]. Although experimental metastasis using B16OVA and EL-4 tumors are well-established assays, they nonetheless have the important caveat of not recapitulating physiological metastasis. We found that whereas tumor development in $T g f b 1^{\mathrm{f} / \mathrm{n}}$-PyMT mice evoked significant secondary tumor development in the lungs, pulmonary tumor metastasis was largely inhibited in $T g f b 1^{\mathrm{f} / \mathrm{n}} \mathrm{Cd} 4 \mathrm{cre}$ PyMT mice that had reached similar primary tumor burden as $T g f b 1^{\mathrm{f} / \mathrm{n}}$-PyMT mice (Figure 2C and 2D). These results collectively establish that TGF- $\beta 1$ produced by $\mathrm{T}$ cells promotes tumor growth and progression and further facilitates secondary niche colonization in PyMT mice. DiscussionTumor growth is a complex phenomenon. In addition to the initiating oncogenic signals, tumors require
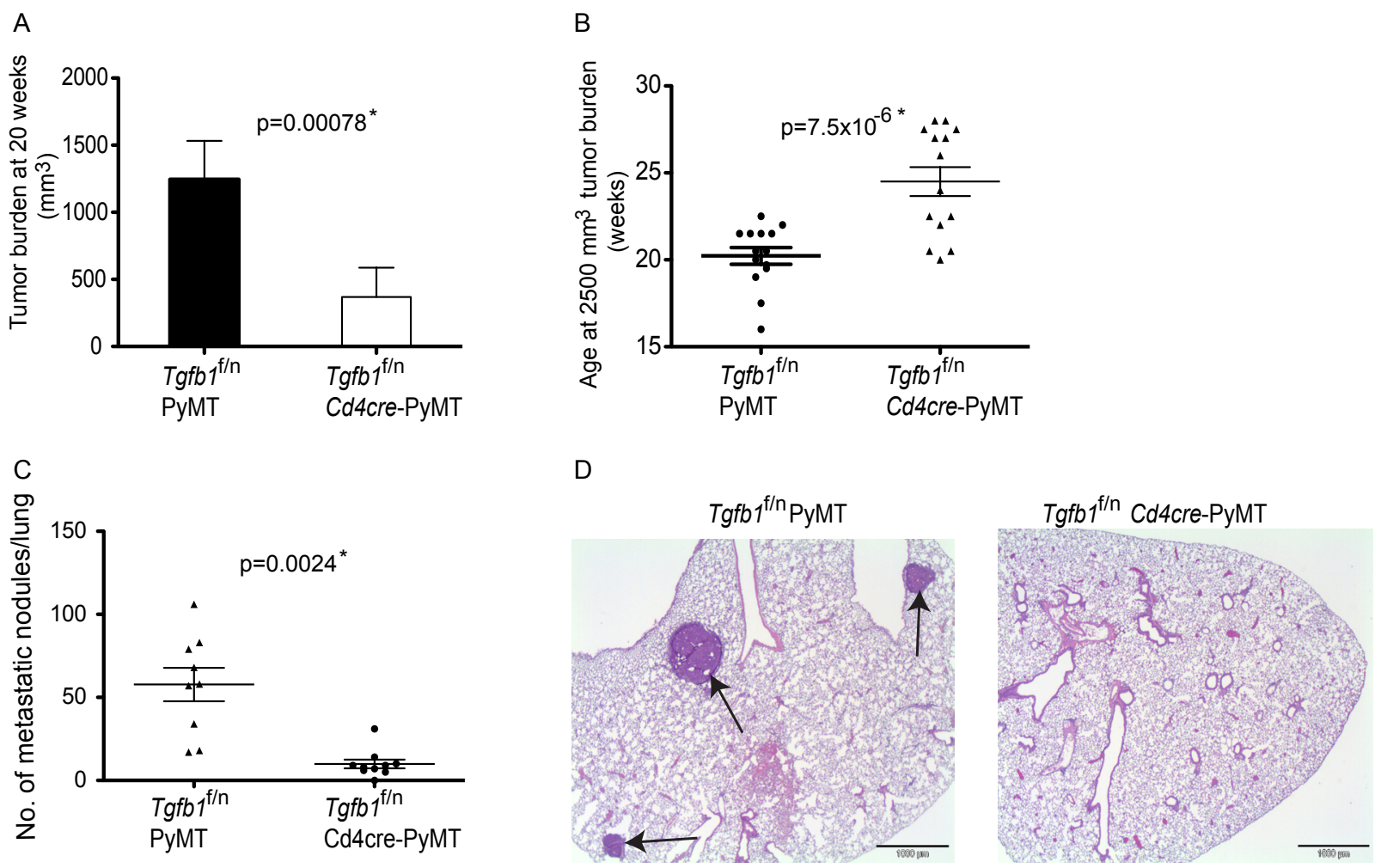

Figure 2: Deficiency of T cell TGF- $\beta 1$ inhibits mammary tumor development. (A) Total tumor burden in all mammary glands of $T g f b 1^{\mathrm{ffn}}$ Cd4cre-PYMT $(\mathrm{n}=14)$ and control $\mathrm{Tgfb}^{\mathrm{f} / \mathrm{n}}$ PYMT $(\mathrm{n}=14)$ mice at 20 weeks of age. Tumor volume was calculated using the formula $\mathrm{L} \mathrm{x} \mathrm{W}{ }^{2} \mathrm{x} 0.52$ (where $\mathrm{L}$ is the longest diameter and $\mathrm{W}$ is the smallest diameter.) (B) The age at which $T g f b 1^{\mathrm{f} / \mathrm{n}} \mathrm{Cd} 4 \mathrm{cre}-\mathrm{PYMT}$ (n=14) and littermate control $T g f b 1^{\mathrm{f} / \mathrm{n}}$ PYMT mice $(\mathrm{n}=14)$ achieved the predetermined tumor burden of $2500 \mathrm{~mm}^{3}$. Tumor volume was calculated using the formula $\mathrm{Lx} \mathrm{W}{ }^{2} \times 0.52$ (where $\mathrm{L}$ is the longest diameter and $\mathrm{W}$ is the smallest diameter.) (C) Total pulmonary metastatic nodules in $T g f b 1^{\mathrm{f} / \mathrm{n}}$ Cd4cre-PYMT (n=9) and control $T g f b 1^{\mathrm{f} / \mathrm{n}}$ PYMT (n=9) mice were assessed at a tumor burden of $2500 \mathrm{~mm}^{3}$. The $\mathrm{p}$ values between the two groups of tumor burden (A) age (B) and number of metastatic nodules (C) are shown (Students t-test). * depicts statistically significant difference. (D) Histological analysis of sections of lungs of $T g f b 1^{\mathrm{f} / \mathrm{n}} C d 4 c r e$-PYMT and $T g f b 1^{\mathrm{f} / \mathrm{n}} \mathrm{PYMT}$ at a tumor burden of $2500 \mathrm{~mm}^{3}$. Sections of representative lungs from $T g f b 1^{\mathrm{f} / \mathrm{n}} \mathrm{PYMT}$ and $T g f b 1^{\mathrm{f} / \mathrm{n}} C d 4 c r e-P Y M T$ mice were stained with hematoxylin and eosin. Black arrows indicate metastatic nodules. 
additional capabilities, which along with a permissive environment, facilitate tumor cell survival, proliferation and metastasis[1]. Studies have implicated the cytokine TGF- $\beta 1$ in tumor initiation and progression[1, 48, 58]. However, because diverse cell types produce TGF- $\beta 1$, defining its cellular source for tumor growth has been challenging. Using a spontaneous model of mammary cancer, we demonstrated that deleting TGF- $\beta 1$ from tumors did not protect mice against tumor development. However, inactivation of TGF- $\beta 1$ in T cells significantly increased tumor latency and inhibited tumor growth. Additionally, we showed that $\mathrm{T}$ cell produced TGF- $\beta 1$ is necessary for tumor progression to higher pathological grades and is further required for the development of secondary tumors in the lungs. These findings reveal $\mathrm{T}$ cells as the critical source of TGF- $\beta 1$ that promotes mammary tumor development.

TGF- $\beta 1$ has long been recognized as a cytokine that promotes tumor development and it is thought that this cytokine mediates tumor growth via its direct effect on tumors $[1,48,58]$. Indeed, mice that express a dominant negative mutant of TGF- $\beta$ RII (DNR) in the prostate epithelium have accelerated tumor development of TRAMP tumors [41], supporting the function of TGF- $\beta 1$ as an enforcer of cytostasis in a variety of cell types[48, 57]. Yet, to what degree physiological TGF- $\beta$ signaling influences tumor development remains incompletely resolved. Studies show that another important target of TGF- $\beta 1$ in tumors is antitumor immune responses[2, $39,48,63]$. In agreement with this observation, we demonstrated recently that $\mathrm{T}$ cell responsiveness to TGF- $\beta$ induces T cell tolerance in TRAMP mice[18]. Accordingly attenuation of TGF- $\beta$ signaling in T cells protects TRAMP mice from tumor development whereas tumors develop normally in control TRAMP mice[18]. In PyMT mice in which TGF- $\beta$ signaling is blocked in T cells, tumor development is similarly inhibited (our unpublished observations). While there is evidence suggesting that TGF- $\beta$ sensitivity by tumors plays an important role for tumor initiation and progression, our data support a model in which the inhibitory effect of TGF- $\beta$ on the immune system is more important and ultimately determines tumor growth and its blockade in $\mathrm{T}$ cells can override these growth advantages TGF- $\beta$ signaling confers to tumors.

A crucial observation in this study is the finding that deletion of TGF- $\beta 1$ from tumor cells did not have any consequences on tumor latency or progression in PyMT mice. Furthermore, we found that tumor-derived TGF- $\beta 1$ is dispensable for $\mathrm{CD}^{+}$and $\mathrm{CD}^{+} \mathrm{T}$ cell differentiation in PyMT mice (data not shown). Many cell types produce TGF- $\beta 1$ and because of the broad distribution of the TGF- $\beta$ receptors, almost every cell type responds to this cytokine[29]. Our findings are in stark contrast to the widely held hypothesis that tumor-derived TGF- $\beta 1$ promotes $\mathrm{T}$ cell tolerance and tumor development [2, $38,44,48,52,53,64]$. The favored mechanism is that tumors, by mechanisms largely unknown but probably involve hypoxia and/or inflammation, acquire the ability to abundantly produce TGF- $\beta 1$ during their evolution which enables the tumors to progress via autocrine effects on tumors and paracrine suppression of immunosurveillance. This model derives from findings described in a study showing that overexpression of active TGF- $\beta 1$ cDNA in immunogenic tumors increased their tumorigenicity and evaded CTL-mediated eradication[53]. Succeeding studies further showed improved antitumor immunity via antibody neutralization of TGF- $\beta$ or tumor cell expression of soluble TGF- $\beta$ RII. However, it is evident that a requirement for tumor-derived TGF- $\beta 1$ in immunotolerance and tumor development cannot be deduced from these observations. Consistent with our findings, a more recent study provided evidence that shRNA-mediated knockdown of tumorderived TGF- $\beta 1$ did not inhibit tumor development in tumor transplantation studies whereas tumor cell expression of soluble TGF- $\beta$ RII did[54]. Whether the development of other spontaneous tumors and, more importantly, human cancers will also prove to be independent of tumor-derived TGF- $\beta 1$ as demonstrated for TRAMP [18] and PyMT tumors is open for future inquiries.

As opposed to tumor-derived TGF- $\beta 1$, deletion of TGF- $\beta 1$ from $\mathrm{T}$ cells significantly increased tumor latency and suppressed tumor development in PyMT mice. However unlike $T g f b 1^{\mathrm{f} / \mathrm{n}} \mathrm{Cd}$ 4cre-TRAMP mice where tumor protection was associated with frank increases in the expression of the effector molecules IFN- $\gamma$ and GzmB by $T$ cells in the tumor-draining lymph nodes and prostates[18], tumor protective immunity in $T g f b 1^{\mathrm{f} /}$ ${ }^{\mathrm{n}} \mathrm{Cd} 4 \mathrm{cre}$-PyMT mice was associated with moderately increased expression of these effector molecules in $T g f b 1^{\mathrm{f} /}$ ${ }^{\mathrm{n}} \mathrm{Cd} 4$ cre-PyMT mice compared to $\mathrm{Tg} f b 1^{\mathrm{f} / \mathrm{n}}$-PyMT mice (data not shown). The IFN- $\gamma$ and the killer cell cytotoxic granule pathways are essential for the rejection of a variety of tumor types[7, 9, 10, 13-15]. However, to what extent the observed responses account for the inhibition of tumor development in these mice remains unclear. Nonetheless, these observations bring to one additional tumor in which deletion of TGF- $\beta 1$ from T cells protects mice against spontaneous tumors. These findings however raise an important question: what special attributes endow TGF- $\beta 1$ produced by $T$ cells with the ability to suppress antitumor immune responses? One possible answer lies in the biological properties of TGF- $\beta 1$. Because TGF- $\beta 1$ is secreted as an inactive latent ligand, it requires activation catalyzed by multiple processes. One well-established in vivo mechanism of activation is via dendritic cell (DC)expressed $\alpha v \beta 8$ integrin[31]. Therefore, we speculate that in the process of priming naïve $T$ cells in the tumordraining lymph nodes, T cells secrete TGF- $\beta 1$, which in turn regulates $T$ cell responses following TGF- $\beta 1$ activation by DCs. There are two data sets to support this speculation. First, in the TRAMP model, we previously 
found that tumor development triggers enhanced TGF$\beta$-dependent Smad2 and Smad3 phosphorylation in the tumor-draining lymph nodes compared to other tissues examined including the prostate[18]. We further showed that TGF- $\beta$ inhibition of $\mathrm{T}$ cell priming in the tumordraining lymph nodes is contributed partly by TGF- $\beta 1$ produced by T cells[18]. Second, and more recently, we found that the inhibitory effect of T cell TGF- $\beta 1$ resides predominantly in activated $\mathrm{Ox} 40^{+} \mathrm{T}$ cells[60]. In an unrelated process, data from pharmacokinetic studies have demonstrated that active TGF- $\beta 1$ has an extremely short half-life of 2-3 $\min [65]$. This short half-life, combined with the ubiquitous expression of TGF- $\beta$ receptors by tumors and cells in the tumor stroma, makes it unlikely for tumor-derived TGF- $\beta 1$ to successfully diffuse to the tumor-draining lymph nodes to regulate $\mathrm{T}$ cell responses.

The propensity of primary tumors to undergo EMT, become invasive, to seed and colonize distant niches has important clinical implications[39, 59]. Tumor metastasis accounts for over $90 \%$ of cancer-related deaths[59]. In human breast cancer, a recent study demonstrated that TGF- $\beta$ plays a key role in priming tumor cells for dissemination and adaptation to secondary locations such as the lung although the cellular source of TGF- $\beta$ that mediates this process was not investigated[57]. We previously found that TGF- $\beta 1$ produced by $\mathrm{T}$ cells is necessary for lung and peritoneal cavity colonization in experimental metastasis assays[18]. In this report, we have further extended these findings by demonstrating that pulmonary metastasis of PyMT tumors is dependent on TGF- $\beta 1$ produced by $T$ cells. In agreement with our previous observations [18], secondary tumor development in the lungs was comparable between $T g f b 1^{1 / n}$-PyMT and $T g f b l^{1 / n} M m t v c r e-P y M T$ mice, formally demonstrating that TGF- $\beta 1$ produced by these tumors is dispensable for autochthonous tumor metastasis. These findings collectively refine and expand upon our previous findings showing that TGF- $\beta 1$ produced by $\mathrm{T}$ cells but not tumors crucially participates in tumor development by suppressing antitumor immune responses to foster primary tumor growth and metastatic dissemination.

The elucidation of the molecular mechanisms that underlie carcinogenesis has led to rapid informed development of many mechanism-based therapies for cancer. Typically, these therapeutic agents inhibit molecular targets that regulate one or more cancer hallmark capabilities. Experimental evidence shows that because of redundancy in signaling pathways or the acquisition of new genetic or epigenetic changes, tumors, more often than not, adapt to the therapeutic agent[66]. Thus, successful eradication of cancer will require various drug combinations that target parallel signaling pathways that undergird one or more cancer hallmarks. Given the side effects associated with inhibiting a single molecular target, this goal seems so far away if not impossible.

Immunotherapy is an emerging viable alternative for cancer therapy. Recent clinical and animal model studies have demonstrated the effectiveness and durability of cancer immunotherapy[67]. The success of Ipilimumab/ Yervoy, recently approved by the FDA for the treatment of metastatic melanoma is a sterling example of how the immune system can be harnessed to fight cancer. The TGF- $\beta$ pathway is an important target for therapeutic intervention in cancer. Indeed, various strategies to modulate TGF- $\beta$ signaling are already in different stages of clinical evaluation including neutralizing antibodies, silencing oligonucleotides and small molecule inhibitors. All these approaches lack specificity because their mechanism is based on targeting TGF- $\beta$ systemically. Our findings suggest that strategies that deliver TGF- $\beta$ blockade specifically to $\mathrm{T}$ cells alone can alleviate immunotolerance and potentially overrule the cellintrinsic hallmarks of cancer. Such rational approaches would not only leverage antitumor immune response but also preserve the cytostatic effects of TGF- $\beta$ on tumors for cancer eradication. Methods

\section{Mice}

PyMT and mice with floxed and null alleles of $T g f b l$ gene have previously been described[56, 68]. PyMT mice were backcrossed to C57BL/6 background for 10 generations. Crossing mice with floxed and null alleles of $T g f b 1$ gene (f/n) with $C D 4$ cre mice generated $T g f b 1^{\mathrm{f} / \mathrm{h}} \mathrm{Cd}$ 4cre mice having $\mathrm{T}$ cell-specific deletion of TGF- $\beta 1$. We subsequently generated $T g f b 1^{\mathrm{f} / \mathrm{n}} \mathrm{Cd} 4 \mathrm{cre}$ PyMT mice by crossing $T g f b 1^{\mathrm{ffn}} \mathrm{Cd} 4 \mathrm{cre}$ to PyMT mice. Tumor cell-specific deletion of TGF- $\beta 1$ was achieved by crossing PyMT ${ }^{\mathrm{f} / \mathrm{n}}$ mice with Mmtvcre mice (Jackson Laboratory, stock\#003553) that had been backcrossed to C57BL/6 background for 10 generations. All mice were maintained under specific pathogen-free conditions, and animal experimentation was conducted in accordance with MSKCC institutional guidelines.

\section{Reverse transcription PCR}

RNA was prepared from FACS-sorted tumor cells and lymph node cells with miRNeasy kit (Qiagen), and was reverse transcribed into cDNA. cDNA was amplified with the primer set for TGF-b1 gene: 5'-ATCCCACCTTTGCCGAGGGTT-3', and 5'-GCTTCCCGAATGTCTGACGTA-3'.Histopathology and pulmonary nodule enumeration

Mammary glands and lungs from sacrificed animals were fixed in $10 \%$ buffered neutral formalin and embedded in paraffin. For macroscopic pulmonary nodule analysis, lungs were fixed in Bouin's fixative and the number of metastases counted with a dissecting microscope. For histopathological analyses, 4-5 $\mu \mathrm{m}$ tissue sections were routinely stained with haematoxylin and 
eosin and microscopically examined for the stages of tumor development. Microscopic samples were semiquantitatively reviewed by identifying tumor stages by area and each stage was expressed as a percentage of the tissue sample. Tumor stage classification followed the criteria as previously described[69].Statistical analysis

Student's t test was used to calculate statistical significance for difference in a particular measurement between groups. A p value of $<0.05$ was considered statistically significant.

\section{ACKNOWLEDGEMENT}

This work was supported by an American cancer society grant (121857-RSG-12-073-01-LIB, M.O.L.) and a CRI predoctoral fellowship (M.K.D.). M.O.L. is a Rita Allen Foundation Scholar.

\section{REFERENCES}

1. Hanahan D, Weinberg RA: Hallmarks of cancer: the next generation. Cell 2011, 144(5):646-674.

2. Rabinovich GA, Gabrilovich D, Sotomayor EM: Immunosuppressive strategies that are mediated by tumor cells. Annu Rev Immunol 2007, 25:267-296.

3. Tlsty TD, Coussens LM: Tumor stroma and regulation of cancer development. Annu Rev Pathol 2006, 1:119-150.

4. Burnet FM: The concept of immunological surveillance. Prog Exp Tumor Res 1957, 13:1-27.

5. Klein G, Klein E: Immune surveillance against virusinduced tumors and nonrejectability of spontaneous tumors: contrasting consequences of host versus tumor evolution. Proc Natl Acad Sci U S A 1977, 74(5):2121-2125.

6. Schreiber RD, Old LJ, Smyth MJ: Cancer immunoediting: integrating immunity's roles in cancer suppression and promotion. Science 2011, 331(6024):1565-1570.

7. Shankaran V, Ikeda H, Bruce AT, White JM, Swanson PE, Old LJ, Schreiber RD: IFNgamma and lymphocytes prevent primary tumour development and shape tumour immunogenicity. Nature 2001, 410(6832):1107-1111.

8. Vesely MD, Kershaw MH, Schreiber RD, Smyth MJ: Natural innate and adaptive immunity to cancer. Annu Rev Immunol 2011, 29:235-271.

9. Koebel CM, Vermi W, Swann JB, Zerafa N, Rodig SJ, Old LJ, Smyth MJ, Schreiber RD: Adaptive immunity maintains occult cancer in an equilibrium state. Nature 2007, 450(7171):903-907.

10. Dighe AS, Richards E, Old LJ, Schreiber RD: Enhanced in vivo growth and resistance to rejection of tumor cells expressing dominant negative IFN gamma receptors. Immunity 1994, 1(6):447-456.

11. Gansbacher B, Bannerji R, Daniels B, Zier K, Cronin K, Gilboa E: Retroviral vector-mediated gamma-interferon gene transfer into tumor cells generates potent and long lasting antitumor immunity. Cancer Res 1990, 50(24):78207825.

12. Hock H, Dorsch M, Kunzendorf U, Qin Z, Diamantstein T, Blankenstein T: Mechanisms of rejection induced by tumor cell-targeted gene transfer of interleukin 2, interleukin 4, interleukin 7, tumor necrosis factor, or interferon gamma. Proc Natl Acad Sci U S A 1993, 90(7):2774-2778.

13. Kagi D, Ledermann B, Burki K, Seiler P, Odermatt B, Olsen KJ, Podack ER, Zinkernagel RM, Hengartner H: Cytotoxicity mediated by $\mathrm{T}$ cells and natural killer cells is greatly impaired in perforin-deficient mice. Nature 1994, 369(6475):31-37.

14. Smyth MJ, Thia KY, Street SE, MacGregor D, Godfrey DI, Trapani JA: Perforin-mediated cytotoxicity is critical for surveillance of spontaneous lymphoma. J Exp Med 2000, 192(5):755-760.

15. Street SE, Zerafa N, Iezzi M, Westwood JA, Stagg J, Musiani P, Smyth MJ: Host perforin reduces tumor number but does not increase survival in oncogene-driven mammary adenocarcinoma. Cancer Res 2007, 67(11):5454-5460.

16. van den Broek ME, Kagi D, Ossendorp F, Toes R, Vamvakas S, Lutz WK, Melief CJ, Zinkernagel RM, Hengartner H: Decreased tumor surveillance in perforindeficient mice. J Exp Med 1996, 184(5):1781-1790.

17. Willimsky G, Blankenstein T: Sporadic immunogenic tumours avoid destruction by inducing T-cell tolerance. Nature 2005, 437(7055):141-146.

18. Donkor MK, Sarkar A, Savage PA, Franklin RA, Johnson LK, Jungbluth AA, Allison JP, Li MO: T cell surveillance of oncogene-induced prostate cancer is impeded by $\mathrm{T}$ cellderived TGF-beta1 cytokine. Immunity 2011, 35(1):123134.

19. Savage PA, Vosseller K, Kang C, Larimore K, Riedel E, Wojnoonski K, Jungbluth AA, Allison JP: Recognition of a ubiquitous self antigen by prostate cancer-infiltrating CD8+ T lymphocytes. Science 2008, 319(5860):215-220.

20. Boon T, Coulie PG, Van den Eynde BJ, van der Bruggen P: Human T cell responses against melanoma. Annu Rev Immunol 2006, 24:175-208.

21. Lee PP, Yee C, Savage PA, Fong L, Brockstedt D, Weber JS, Johnson D, Swetter S, Thompson J, Greenberg PD et al: Characterization of circulating $\mathrm{T}$ cells specific for tumorassociated antigens in melanoma patients. Nat Med 1999, 5(6):677-685.

22. Blankenstein $\mathrm{T}$ : Do autochthonous tumors interfere with effector T cell responses? Semin Cancer Biol 2007, 17(4):267-274.

23. Drake CG, Jaffee E, Pardoll DM: Mechanisms of immune evasion by tumors. Adv Immunol 2006, 90:51-81.

24. Joyce JA, Pollard JW: Microenvironmental regulation of metastasis. Nat Rev Cancer 2009, 9(4):239-252.

25. Willimsky G, Czeh M, Loddenkemper C, Gellermann J, Schmidt K, Wust $\mathrm{P}$, Stein $\mathrm{H}$, Blankenstein $\mathrm{T}$ : Immunogenicity of premalignant lesions is the primary 
cause of general cytotoxic T lymphocyte unresponsiveness. J Exp Med 2008, 205(7):1687-1700.

26. Buck MB, Fritz P, Dippon J, Zugmaier G, Knabbe C: Prognostic significance of transforming growth factor beta receptor II in estrogen receptor-negative breast cancer patients. Clin Cancer Res 2004, 10(2):491-498.

27. Lawrence DA, Pircher R, Kryceve-Martinerie C, Jullien P: Normal embryo fibroblasts release transforming growth factors in a latent form. J Cell Physiol 1984, 121(1):184188.

28. Li MO, Wan YY, Sanjabi S, Robertson AK, Flavell RA: Transforming growth factor-beta regulation of immune responses. Annu Rev Immunol 2006, 24:99-146.

29. Massague J, Gomis RR: The logic of TGFbeta signaling. FEBS Lett 2006, 580(12):2811-2820.

30. Miyazono K, Ichijo $\mathrm{H}$, Heldin $\mathrm{CH}$ : Transforming growth factor-beta: latent forms, binding proteins and receptors. Growth Factors 1993, 8(1):11-22.

31. Travis MA, Reizis B, Melton AC, Masteller E, Tang Q, Proctor JM, Wang Y, Bernstein X, Huang X, Reichardt LF et al: Loss of integrin alpha(v)beta8 on dendritic cells causes autoimmunity and colitis in mice. Nature 2007, 449(7160):361-365.

32. Li MO, Flavell RA: TGF-beta: a master of all T cell trades. Cell 2008, 134(3):392-404.

33. Gorelik L, Fields PE, Flavell RA: Cutting edge: TGFbeta inhibits Th type 2 development through inhibition of GATA-3 expression. J Immunol 2000, 165(9):4773-4777.

34. Kehrl JH, Wakefield LM, Roberts AB, Jakowlew S, Alvarez-Mon M, Derynck R, Sporn MB, Fauci AS: Production of transforming growth factor beta by human $\mathrm{T}$ lymphocytes and its potential role in the regulation of $\mathrm{T}$ cell growth. J Exp Med 1986, 163(5):1037-1050.

35. McKarns SC, Schwartz RH: Distinct effects of TGF-beta 1 on CD4+ and CD8+ T cell survival, division, and IL-2 production: a role for $\mathrm{T}$ cell intrinsic Smad3. J Immunol 2005, 174(4):2071-2083.

36. Neurath MF, Weigmann B, Finotto S, Glickman J, Nieuwenhuis E, Iijima H, Mizoguchi A, Mizoguchi E, Mudter J, Galle PR et al: The transcription factor T-bet regulates mucosal $\mathrm{T}$ cell activation in experimental colitis and Crohn's disease. J Exp Med 2002, 195(9):1129-1143.

37. Ouyang W, Beckett O, Ma Q, Li MO: Transforming growth factor-beta signaling curbs thymic negative selection promoting regulatory T cell development. Immunity 2010, 32(5):642-653.

38. Wojtowicz-Praga S: Reversal of tumor-induced immunosuppression by TGF-beta inhibitors. Invest New Drugs 2003, 21(1):21-32.

39. Padua D, Massague J: Roles of TGFbeta in metastasis. Cell Res 2009, 19(1):89-102.

40. Siegel PM, Massague J: Cytostatic and apoptotic actions of TGF-beta in homeostasis and cancer. Nat Rev Cancer 2003,
3(11):807-821.

41. Pu H, Collazo J, Jones E, Gayheart D, Sakamoto S, Vogt A, Mitchell B, Kyprianou N: Dysfunctional transforming growth factor-beta receptor II accelerates prostate tumorigenesis in the TRAMP mouse model. Cancer Res 2009, 69(18):7366-7374.

42. Bierie B, Moses HL: Tumour microenvironment: TGFbeta: the molecular Jekyll and Hyde of cancer. Nat Rev Cancer 2006, 6(7):506-520.

43. Levy L, Hill CS: Alterations in components of the TGF-beta superfamily signaling pathways in human cancer. Cytokine Growth Factor Rev 2006, 17(1-2):41-58.

44. Kao JY, Gong Y, Chen CM, Zheng QD, Chen JJ: Tumorderived TGF-beta reduces the efficacy of dendritic cell/ tumor fusion vaccine. J Immunol 2003, 170(7):3806-3811.

45. Nam JS, Terabe M, Mamura M, Kang MJ, Chae H, Stuelten C, Kohn E, Tang B, Sabzevari H, Anver MR et al: An anti-transforming growth factor beta antibody suppresses metastasis via cooperative effects on multiple cell compartments. Cancer Res 2008, 68(10):3835-3843.

46. Zhang Q, Yang X, Pins M, Javonovic B, Kuzel T, Kim SJ, Parijs LV, Greenberg NM, Liu V, Guo Y et al: Adoptive transfer of tumor-reactive transforming growth factor-betainsensitive CD8+ T cells: eradication of autologous mouse prostate cancer. Cancer Res 2005, 65(5):1761-1769.

47. Zhang Q, Yang XJ, Kundu SD, Pins M, Javonovic B, Meyer R, Kim SJ, Greenberg NM, Kuzel T, Meagher R et al: Blockade of transforming growth factor-\{beta\} signaling in tumor-reactive $\mathrm{CD} 8(+) \mathrm{T}$ cells activates the antitumor immune response cycle. Mol Cancer Ther 2006, 5(7):17331743.

48. Massague J: TGFbeta in Cancer. Cell 2008, 134(2):215230.

49. Thompson NL, Flanders KC, Smith JM, Ellingsworth LR, Roberts AB, Sporn MB: Expression of transforming growth factor-beta 1 in specific cells and tissues of adult and neonatal mice. J Cell Biol 1989, 108(2):661-669.

50. Yang L, Huang J, Ren X, Gorska AE, Chytil A, Aakre M, Carbone DP, Matrisian LM, Richmond A, Lin PC et al: Abrogation of TGF beta signaling in mammary carcinomas recruits $\mathrm{Gr}-1+\mathrm{CD} 11 \mathrm{~b}+$ myeloid cells that promote metastasis. Cancer Cell 2008, 13(1):23-35.

51. Friese MA, Wischhusen J, Wick W, Weiler M, Eisele G, Steinle A, Weller M: RNA interference targeting transforming growth factor-beta enhances NKG2Dmediated antiglioma immune response, inhibits glioma cell migration and invasiveness, and abrogates tumorigenicity in vivo. Cancer Res 2004, 64(20):7596-7603.

52. Liu VC, Wong LY, Jang T, Shah AH, Park I, Yang X, Zhang Q, Lonning S, Teicher BA, Lee C: Tumor evasion of the immune system by converting CD4+CD25- T cells into CD4+CD25+ T regulatory cells: role of tumor-derived TGF-beta. J Immunol 2007, 178(5):2883-2892.

53. Torre-Amione G, Beauchamp RD, Koeppen H, Park 
BH, Schreiber H, Moses HL, Rowley DA: A highly immunogenic tumor transfected with a murine transforming growth factor type beta 1 cDNA escapes immune surveillance. Proc Natl Acad Sci U S A 1990, 87(4):14861490.

54. Thomas DA, Massague J: TGF-beta directly targets cytotoxic $\mathrm{T}$ cell functions during tumor evasion of immune surveillance. Cancer Cell 2005, 8(5):369-380.

55. Wagner KU, Wall RJ, St-Onge L, Gruss P, WynshawBoris A, Garrett L, Li M, Furth PA, Hennighausen L: Cremediated gene deletion in the mammary gland. Nucleic Acids Res 1997, 25(21):4323-4330.

56. Guy CT, Cardiff RD, Muller WJ: Induction of mammary tumors by expression of polyomavirus middle $\mathrm{T}$ oncogene: a transgenic mouse model for metastatic disease. Mol Cell Biol 1992, 12(3):954-961.

57. Padua D, Zhang XH, Wang Q, Nadal C, Gerald WL, Gomis RR, Massague J: TGFbeta primes breast tumors for lung metastasis seeding through angiopoietin-like 4. Cell 2008, 133(1):66-77.

58. Yang L: TGFbeta and cancer metastasis: an inflammation link. Cancer Metastasis Rev 2010, 29(2):263-271.

59. Hanahan D, Weinberg RA: The hallmarks of cancer. Cell 2000, 100(1):57-70.

60. Donkor MK, Sarkar A, Li MO: TGF- $\beta 1$ Produced by Activated CD4+ T Cells Antagonizes T Cell Surveillance of Tumor Development

Oncoimmunology 2011, 1(2):In press.

61. Minn AJ, Gupta GP, Padua D, Bos P, Nguyen DX, Nuyten D, Kreike B, Zhang Y, Wang Y, Ishwaran H et al: Lung metastasis genes couple breast tumor size and metastatic spread. Proc Natl Acad Sci U S A 2007, 104(16):67406745.

62. Dalton LW, Pinder SE, Elston CE, Ellis IO, Page DL, Dupont WD, Blamey RW: Histologic grading of breast cancer: linkage of patient outcome with level of pathologist agreement. Mod Pathol 2000, 13(7):730-735.

63. Li MO, Flavell RA: TGF-beta, T-cell tolerance and immunotherapy of autoimmune diseases and cancer. Expert Rev Clin Immunol 2006, 2(2):257-265.

64. Wick W, Naumann U, Weller M: Transforming growth factor-beta: a molecular target for the future therapy of glioblastoma. Curr Pharm Des 2006, 12(3):341-349.

65. Wakefield LM, Winokur TS, Hollands RS, Christopherson $\mathrm{K}$, Levinson $\mathrm{AD}$, Sporn MB: Recombinant latent transforming growth factor beta 1 has a longer plasma half-life in rats than active transforming growth factor beta 1, and a different tissue distribution. J Clin Invest 1990, 86(6):1976-1984.

66. Bergers G, Hanahan D: Modes of resistance to antiangiogenic therapy. Nat Rev Cancer 2008, 8(8):592-603.

67. Sharma P, Wagner K, Wolchok JD, Allison JP: Novel cancer immunotherapy agents with survival benefit: recent successes and next steps. Nat Rev Cancer 2011, 11(11):805-
812.

68. Li MO, Wan YY, Flavell RA: T cell-produced transforming growth factor-betal controls $\mathrm{T}$ cell tolerance and regulates Th1- and Th17-cell differentiation. Immunity 2007, 26(5):579-591.

69. Lin EY, Jones JG, Li P, Zhu L, Whitney KD, Muller WJ, Pollard JW: Progression to malignancy in the polyoma middle $\mathrm{T}$ oncoprotein mouse breast cancer model provides a reliable model for human diseases. Am J Pathol 2003, 163(5):2113-2126.

\section{REFERENCES}

1. Hanahan D, Weinberg RA: Hallmarks of cancer: the next generation. Cell 2011, 144(5):646-674.

2. Rabinovich GA, Gabrilovich D, Sotomayor EM: Immunosuppressive strategies that are mediated by tumor cells. Annu Rev Immunol 2007, 25:267-296.

3. Tlsty TD, Coussens LM: Tumor stroma and regulation of cancer development. Annu Rev Pathol 2006, 1:119-150.

4. Burnet FM: The concept of immunological surveillance. Prog Exp Tumor Res 1957, 13:1-27.

5. Klein G, Klein E: Immune surveillance against virusinduced tumors and nonrejectability of spontaneous tumors: contrasting consequences of host versus tumor evolution. Proc Natl Acad Sci U S A 1977, 74(5):2121-2125.

6. Schreiber RD, Old LJ, Smyth MJ: Cancer immunoediting: integrating immunity's roles in cancer suppression and promotion. Science 2011, 331(6024):1565-1570.

7. Shankaran V, Ikeda H, Bruce AT, White JM, Swanson PE, Old LJ, Schreiber RD: IFNgamma and lymphocytes prevent primary tumour development and shape tumour immunogenicity. Nature 2001, 410(6832):1107-1111.

8. Vesely MD, Kershaw MH, Schreiber RD, Smyth MJ: Natural innate and adaptive immunity to cancer. Annu Rev Immunol 2011, 29:235-271.

9. Koebel CM, Vermi W, Swann JB, Zerafa N, Rodig SJ, Old LJ, Smyth MJ, Schreiber RD: Adaptive immunity maintains occult cancer in an equilibrium state. Nature 2007, 450(7171):903-907.

10. Dighe AS, Richards E, Old LJ, Schreiber RD: Enhanced in vivo growth and resistance to rejection of tumor cells expressing dominant negative IFN gamma receptors. Immunity 1994, 1(6):447-456.

11. Gansbacher B, Bannerji R, Daniels B, Zier K, Cronin K, Gilboa E: Retroviral vector-mediated gamma-interferon gene transfer into tumor cells generates potent and long lasting antitumor immunity. Cancer Res 1990, 50(24):78207825 .

12. Hock H, Dorsch M, Kunzendorf U, Qin Z, Diamantstein T, Blankenstein T: Mechanisms of rejection induced by tumor cell-targeted gene transfer of interleukin 2, interleukin 4, interleukin 7, tumor necrosis factor, or interferon gamma. 
Proc Natl Acad Sci U S A 1993, 90(7):2774-2778.

13. Kagi D, Ledermann B, Burki K, Seiler P, Odermatt B, Olsen KJ, Podack ER, Zinkernagel RM, Hengartner H: Cytotoxicity mediated by $\mathrm{T}$ cells and natural killer cells is greatly impaired in perforin-deficient mice. Nature 1994, 369(6475):31-37

14. Smyth MJ, Thia KY, Street SE, MacGregor D, Godfrey DI, Trapani JA: Perforin-mediated cytotoxicity is critical for surveillance of spontaneous lymphoma. J Exp Med 2000, 192(5):755-760.

15. Street SE, Zerafa N, Iezzi M, Westwood JA, Stagg J, Musiani P, Smyth MJ: Host perforin reduces tumor number but does not increase survival in oncogene-driven mammary adenocarcinoma. Cancer Res 2007, 67(11):5454-5460.

16. van den Broek ME, Kagi D, Ossendorp F, Toes R, Vamvakas S, Lutz WK, Melief CJ, Zinkernagel RM, Hengartner H: Decreased tumor surveillance in perforindeficient mice. J Exp Med 1996, 184(5):1781-1790.

17. Willimsky G, Blankenstein T: Sporadic immunogenic tumours avoid destruction by inducing T-cell tolerance. Nature 2005, 437(7055):141-146.

18. Donkor MK, Sarkar A, Savage PA, Franklin RA, Johnson LK, Jungbluth AA, Allison JP, Li MO: T cell surveillance of oncogene-induced prostate cancer is impeded by $\mathrm{T}$ cellderived TGF-beta1 cytokine. Immunity 2011, 35(1):123134.

19. Savage PA, Vosseller K, Kang C, Larimore K, Riedel E, Wojnoonski K, Jungbluth AA, Allison JP: Recognition of a ubiquitous self antigen by prostate cancer-infiltrating CD8+ T lymphocytes. Science 2008, 319(5860):215-220.

20. Boon T, Coulie PG, Van den Eynde BJ, van der Bruggen P: Human T cell responses against melanoma. Annu Rev Immunol 2006, 24:175-208.

21. Lee PP, Yee C, Savage PA, Fong L, Brockstedt D, Weber JS, Johnson D, Swetter S, Thompson J, Greenberg PD et al: Characterization of circulating $\mathrm{T}$ cells specific for tumorassociated antigens in melanoma patients. Nat Med 1999, 5(6):677-685.

22. Blankenstein $\mathrm{T}$ : Do autochthonous tumors interfere with effector T cell responses? Semin Cancer Biol 2007, 17(4):267-274.

23. Drake CG, Jaffee E, Pardoll DM: Mechanisms of immune evasion by tumors. Adv Immunol 2006, 90:51-81.

24. Joyce JA, Pollard JW: Microenvironmental regulation of metastasis. Nat Rev Cancer 2009, 9(4):239-252.

25. Willimsky G, Czeh M, Loddenkemper C, Gellermann J, Schmidt K, Wust P, Stein H, Blankenstein T: Immunogenicity of premalignant lesions is the primary cause of general cytotoxic T lymphocyte unresponsiveness. J Exp Med 2008, 205(7):1687-1700.

26. Buck MB, Fritz P, Dippon J, Zugmaier G, Knabbe C: Prognostic significance of transforming growth factor beta receptor II in estrogen receptor-negative breast cancer patients. Clin Cancer Res 2004, 10(2):491-498.

27. Lawrence DA, Pircher R, Kryceve-Martinerie C, Jullien P: Normal embryo fibroblasts release transforming growth factors in a latent form. J Cell Physiol 1984, 121(1):184188.

28. Li MO, Wan YY, Sanjabi S, Robertson AK, Flavell RA: Transforming growth factor-beta regulation of immune responses. Annu Rev Immunol 2006, 24:99-146.

29. Massague J, Gomis RR: The logic of TGFbeta signaling. FEBS Lett 2006, 580(12):2811-2820.

30. Miyazono K, Ichijo H, Heldin CH: Transforming growth factor-beta: latent forms, binding proteins and receptors. Growth Factors 1993, 8(1):11-22.

31. Travis MA, Reizis B, Melton AC, Masteller E, Tang Q, Proctor JM, Wang Y, Bernstein X, Huang X, Reichardt LF et al: Loss of integrin alpha(v)beta8 on dendritic cells causes autoimmunity and colitis in mice. Nature 2007, 449(7160):361-365.

32. Li MO, Flavell RA: TGF-beta: a master of all T cell trades. Cell 2008, 134(3):392-404.

33. Gorelik L, Fields PE, Flavell RA: Cutting edge: TGFbeta inhibits Th type 2 development through inhibition of GATA-3 expression. J Immunol 2000, 165(9):4773-4777.

34. Kehrl JH, Wakefield LM, Roberts AB, Jakowlew S, Alvarez-Mon M, Derynck R, Sporn MB, Fauci AS: Production of transforming growth factor beta by human $\mathrm{T}$ lymphocytes and its potential role in the regulation of $\mathrm{T}$ cell growth. J Exp Med 1986, 163(5):1037-1050.

35. McKarns SC, Schwartz RH: Distinct effects of TGF-beta 1 on CD4+ and CD8+ T cell survival, division, and IL-2 production: a role for $\mathrm{T}$ cell intrinsic Smad3. J Immunol 2005, 174(4):2071-2083.

36. Neurath MF, Weigmann B, Finotto S, Glickman J, Nieuwenhuis E, Iijima H, Mizoguchi A, Mizoguchi E, Mudter J, Galle PR et al: The transcription factor T-bet regulates mucosal $\mathrm{T}$ cell activation in experimental colitis and Crohn's disease. J Exp Med 2002, 195(9):1129-1143.

37. Ouyang W, Beckett O, Ma Q, Li MO: Transforming growth factor-beta signaling curbs thymic negative selection promoting regulatory T cell development. Immunity 2010, 32(5):642-653.

38. Wojtowicz-Praga S: Reversal of tumor-induced immunosuppression by TGF-beta inhibitors. Invest New Drugs 2003, 21(1):21-32.

39. Padua D, Massague J: Roles of TGFbeta in metastasis. Cell Res 2009, 19(1):89-102.

40. Siegel PM, Massague J: Cytostatic and apoptotic actions of TGF-beta in homeostasis and cancer. Nat Rev Cancer 2003, 3(11):807-821.

41. Pu H, Collazo J, Jones E, Gayheart D, Sakamoto S, Vogt A, Mitchell B, Kyprianou N: Dysfunctional transforming growth factor-beta receptor II accelerates prostate tumorigenesis in the TRAMP mouse model. Cancer Res 
2009, 69(18):7366-7374.

42. Bierie B, Moses HL: Tumour microenvironment: TGFbeta: the molecular Jekyll and Hyde of cancer. Nat Rev Cancer 2006, 6(7):506-520.

43. Levy L, Hill CS: Alterations in components of the TGF-beta superfamily signaling pathways in human cancer. Cytokine Growth Factor Rev 2006, 17(1-2):41-58.

44. Kao JY, Gong Y, Chen CM, Zheng QD, Chen JJ: Tumorderived TGF-beta reduces the efficacy of dendritic cell/ tumor fusion vaccine. J Immunol 2003, 170(7):3806-3811.

45. Nam JS, Terabe M, Mamura M, Kang MJ, Chae H, Stuelten C, Kohn E, Tang B, Sabzevari H, Anver MR et al: An anti-transforming growth factor beta antibody suppresses metastasis via cooperative effects on multiple cell compartments. Cancer Res 2008, 68(10):3835-3843.

46. Zhang Q, Yang X, Pins M, Javonovic B, Kuzel T, Kim SJ, Parijs LV, Greenberg NM, Liu V, Guo Y et al: Adoptive transfer of tumor-reactive transforming growth factor-betainsensitive CD8 + T cells: eradication of autologous mouse prostate cancer. Cancer Res 2005, 65(5):1761-1769.

47. Zhang Q, Yang XJ, Kundu SD, Pins M, Javonovic B, Meyer R, Kim SJ, Greenberg NM, Kuzel T, Meagher R et al: Blockade of transforming growth factor-\{beta\} signaling in tumor-reactive $\mathrm{CD} 8(+) \mathrm{T}$ cells activates the antitumor immune response cycle. Mol Cancer Ther 2006, 5(7):17331743.

48. Massague J: TGFbeta in Cancer. Cell 2008, 134(2):215230.

49. Thompson NL, Flanders KC, Smith JM, Ellingsworth LR, Roberts AB, Sporn MB: Expression of transforming growth factor-beta 1 in specific cells and tissues of adult and neonatal mice. J Cell Biol 1989, 108(2):661-669.

50. Yang L, Huang J, Ren X, Gorska AE, Chytil A, Aakre M, Carbone DP, Matrisian LM, Richmond A, Lin PC et al: Abrogation of TGF beta signaling in mammary carcinomas recruits $\mathrm{Gr}-1+\mathrm{CD} 11 \mathrm{~b}+$ myeloid cells that promote metastasis. Cancer Cell 2008, 13(1):23-35.

51. Friese MA, Wischhusen J, Wick W, Weiler M, Eisele G, Steinle A, Weller M: RNA interference targeting transforming growth factor-beta enhances NKG2Dmediated antiglioma immune response, inhibits glioma cell migration and invasiveness, and abrogates tumorigenicity in vivo. Cancer Res 2004, 64(20):7596-7603.

52. Liu VC, Wong LY, Jang T, Shah AH, Park I, Yang X, Zhang Q, Lonning S, Teicher BA, Lee C: Tumor evasion of the immune system by converting CD4+CD25- T cells into CD4+CD25+ T regulatory cells: role of tumor-derived TGF-beta. J Immunol 2007, 178(5):2883-2892.

53. Torre-Amione G, Beauchamp RD, Koeppen H, Park $\mathrm{BH}$, Schreiber H, Moses HL, Rowley DA: A highly immunogenic tumor transfected with a murine transforming growth factor type beta 1 cDNA escapes immune surveillance. Proc Natl Acad Sci U S A 1990, 87(4):1486-
1490.

54. Thomas DA, Massague J: TGF-beta directly targets cytotoxic $\mathrm{T}$ cell functions during tumor evasion of immune surveillance. Cancer Cell 2005, 8(5):369-380.

55. Wagner KU, Wall RJ, St-Onge L, Gruss P, WynshawBoris A, Garrett L, Li M, Furth PA, Hennighausen L: Cremediated gene deletion in the mammary gland. Nucleic Acids Res 1997, 25(21):4323-4330.

56. Guy CT, Cardiff RD, Muller WJ: Induction of mammary tumors by expression of polyomavirus middle $\mathrm{T}$ oncogene: a transgenic mouse model for metastatic disease. Mol Cell Biol 1992, 12(3):954-961.

57. Padua D, Zhang XH, Wang Q, Nadal C, Gerald WL, Gomis RR, Massague J: TGFbeta primes breast tumors for lung metastasis seeding through angiopoietin-like 4. Cell 2008, 133(1):66-77.

58. Yang L: TGFbeta and cancer metastasis: an inflammation link. Cancer Metastasis Rev 2010, 29(2):263-271.

59. Hanahan D, Weinberg RA: The hallmarks of cancer. Cell 2000, 100(1):57-70.

60. Donkor MK, Sarkar A, Li MO: TGF- $\beta 1$ Produced by Activated CD4+ T Cells Antagonizes T Cell Surveillance of Tumor Development

Oncoimmunology 2011, 1(2):In press.

61. Minn AJ, Gupta GP, Padua D, Bos P, Nguyen DX, Nuyten D, Kreike B, Zhang Y, Wang Y, Ishwaran H et al: Lung metastasis genes couple breast tumor size and metastatic spread. Proc Natl Acad Sci U S A 2007, 104(16):67406745 .

62. Dalton LW, Pinder SE, Elston CE, Ellis IO, Page DL, Dupont WD, Blamey RW: Histologic grading of breast cancer: linkage of patient outcome with level of pathologist agreement. Mod Pathol 2000, 13(7):730-735.

63. Li MO, Flavell RA: TGF-beta, T-cell tolerance and immunotherapy of autoimmune diseases and cancer. Expert Rev Clin Immunol 2006, 2(2):257-265.

64. Wick W, Naumann U, Weller M: Transforming growth factor-beta: a molecular target for the future therapy of glioblastoma. Curr Pharm Des 2006, 12(3):341-349.

65. Wakefield LM, Winokur TS, Hollands RS, Christopherson $\mathrm{K}$, Levinson AD, Sporn MB: Recombinant latent transforming growth factor beta 1 has a longer plasma half-life in rats than active transforming growth factor beta 1, and a different tissue distribution. J Clin Invest 1990, 86(6):1976-1984.

66. Bergers G, Hanahan D: Modes of resistance to antiangiogenic therapy. Nat Rev Cancer 2008, 8(8):592-603.

67. Sharma P, Wagner K, Wolchok JD, Allison JP: Novel cancer immunotherapy agents with survival benefit: recent successes and next steps. Nat Rev Cancer 2011, 11(11):805812.

68. Li MO, Wan YY, Flavell RA: T cell-produced transforming growth factor-betal controls $\mathrm{T}$ cell tolerance and regulates Th1- and Th17-cell differentiation. Immunity 2007, 
26(5):579-591.

69. Lin EY, Jones JG, Li P, Zhu L, Whitney KD, Muller WJ, Pollard JW: Progression to malignancy in the polyoma middle $\mathrm{T}$ oncoprotein mouse breast cancer model provides a reliable model for human diseases. Am J Pathol 2003, 163(5):2113-2126. 